\title{
REPRODUCTION IN THE HEAT-ACCLIMATIZED FEMALE RAT AS AFFECTED BY HIGH AMBIENT TEMPERATURE
}

\author{
U. A. SOD-MORIAH \\ Division of Life Sciences, Negev Institute for Arid Zone Research, \\ Beer-Sheva, Israel
}

(Received 19th September 1970)

\begin{abstract}
Summary. The effect of continuous high environmental temperature $\left(35 \pm 1^{\circ} \mathrm{C}\right)$ on various phases of the reproductive cycle was studied in heat-acclimatized female rats kept on an adequate diet. Results were compared with those of control animals maintained at $22 \pm 3^{\circ} \mathrm{C}$.

Heat increased the irregularity and mean duration of the oestrous cycle thus reducing the number of cycles occurring during a given period of time. The number of CL produced was not affected although fewer ova could be recovered from the Fallopian tubes on the 1st day of pregnancy. The fertilization rate of ova recovered also remained unaffected. The number of ova degenerating by the 4th day of gestation increased, but there was no apparent adverse effect on the timing and the rate of implantation. During the postimplantation period, the rates of foetal resorption and perinatal death increased. The mean duration of gestation did not seem to change. It is suggested that the process of parturition was affected since, in heat-treated rats, it lasted longer, was more irregular in timing and was inhibited completely in $29 \%$ of the animals examined.
\end{abstract}

\section{INTRODUCTION}

There is good evidence that female rats exposed to high environmental temperatures produce fewer viable young than controls at more moderate temperatures (Sundstroem, 1927, 1930; Macfarlane, Pennycuik \& Thrift, 1957; Macfarlane, Pennycuik, Yeates \& Thrift, 1959; Pennycuik, 1964c). There is also evidence that this is due to disturbances at various points of the reproductive cycle, i.e. a longer and more irregular oestrous cycle (Sundstroem, 1930; Macfarlane et al., 1959; Pennycuik, 1964c; Sod-Moriah \& Pollack, 1970), reduced ovulation rate (Macfarlane et al., 1957; Macfarlane et al., 1959; Pennycuik, 1964c), impaired development of fertilized ova (Pennycuik, 1964c; Sod-Mariah \& Pollack, 1970), disturbances in implantation (Macfarlane et al., 1959), foetal resorption (Sundstroem, 1927, 1930; Macfarlane et al., 1957; Macfarlane et al., 1959; Pennycuik, 1964c) and prolonged pregnancies which are associated with increased mortality among the young at birth (Macfarlane et al., 1959; Pennycuik, 1964c). However, the relative importance of these 
disturbances in reducing the number of viable offspring is disputed. These dissimilarities could be due to strain differences (Yeates, 1956; Hafez, 1968) and to inadequate nutrition (Macfarlane et al., 1957; Pennycuik, 1964a, b). It is also possible that some are due to the differences in experimental temperatures, and to the duration of the exposure (Sundstroem, 1930; Macfarlane et al., 1957; Pennycuik, 1964c; Sod-Moriah \& Pollack, 1970).

In this study, we examined the effects of exposure to $35^{\circ} \mathrm{C}$ on the reproduction of female rats which were previously acclimatized to this temperature. Complications due to nutritional inadequacies were avoided by supplying a rich diet.

\section{MATERIALS AND METHODS}

The experiment was carried out on 120 cycling, virgin female, white rats from the colony of the Department of Biodynamics, Weizmann Institute of Science, Rehovoth. The rats were 110 to 120 days old when they were obtained. Animals were randomly assigned to two groups, control and heat-acclimatized, each consisting of sixty rats. The control group was kept in a room maintained at $22 \pm 3^{\circ} \mathrm{C}$ and at a relative humidity of 40 to $70 \%$. The heat-treated group was kept in a hot room maintained at $35 \pm 1^{\circ} \mathrm{C}$ and at a relative humidity of 15 to $30 \%$. The lighting regimen in both rooms was $10 \mathrm{hr}$ darkness/14 hr light. Animals were housed in stainless steel boxes which were fitted with a wire mesh floor (gauge $1.5 \times 1.5 \mathrm{~cm}$ ). Two rats, separated by a wire mesh partition, were kept in each box. Water and pelleted rat chow (Sod-Moriah \& Pollack, 1970) were freely available.

Animals were acclimatized to their respective temperatures for 30 days before the commencement of the experiment. After this initial period, vaginal smears were taken daily for a 40-day period during which the oestrous cycle of the animals was studied. Thereafter, animals found in the pro-oestrous stage were placed overnight with a fertile male in the control room. Mating was confirmed by the detection of spermatozoa in the vaginal smear the following morning.

The mated animals in each group were then sub-divided into three groups of controls and three of heat-acclimatized females, each group consisting of twenty animals. One control and one heat-acclimatized group were killed with an overdose of ether on Day 1 of gestation (the day of detection of spermatozoa in the vaginal smear) between 10.00 hours and 14.00 hours. Each Fallopian tube was exposed and the lateral loop containing the cumulus mass including the ova was identified under a dissecting microscope, excised and put into a watch glass containing saline. The cumulus mass containing the ova was released by opening the loop. The ova were identified and counted. After separation by repipetting through a micropipette, the ova were transferred in a drop of saline to a microscope slide. In order to avoid subjecting the ova to excessive pressure, four dots of Celloseal grease (Fisher Scientific Company, Pittsburgh) containing glass micro-beads 70 to $80 \mu \mathrm{m}$ in diameter were placed on the slide in such a way that they supported the four corners of a coverslip placed on the saline drop containing the ova (Kraicer, 1967). Each ovum was checked at a magnification 
of $\times 640$ for the presence of the second polar body and two pronuclei. If these organelles were not identified, the ovum was classified as unfertilized.

Pregnancies were allowed to continue until Day 4 in two other groups of rats, one control and the other heat-acclimatized, each group consisting of twenty animals. On the morning of Day 1, upon detection of spermatozoa in the vaginal smear, the respective animals were injected intraperitoneally with $1.0 \mathrm{ml}$ of a $1 \%$ trypan blue solution to facilitate identification of the newly formed corpora lutea (cL). Between 10.00 hours and 14.00 hours on Day 4, animals were killed with an overdose of ether and the ovaries with the attached Fallopian tubes and the cephalic third of the uterine horns were excised. Under a dissecting microscope, the orifice of each Fallopian tube was exposed and a blunt 27-gauge needle inserted. The contents of the tube and attached uterine horn were then flushed into a watch glass with $0.5 \mathrm{ml}$ saline. The contents of each horn were collected separately. After being counted, the ova were transferred in a drop of saline to a microscope slide, covered as described, and then classified into developing ova (morulae and early blastocysts) or degenerating ova. All ova in which the zona pellucida contained foamy fragmented material and no visible cells were classified in the latter category.

The remaining two groups of twenty control and twenty heat-acclimatized rats were allowed to complete their pregnancies. Vaginal smears were taken daily from each animal until the 'placental sign' (Venable, 1939) was observed. The duration of pregnancy in each animal was determined by counting the days between Day 1 and parturition. Animals which were not delivered by the 33rd day were killed and the uterine horns were opened to release the macerated embryos. In those animals which were delivered spontaneously, young fell through the wire-mesh floor (with very few exceptions) to the paper-covered floor of the stainless-steel boxes. Live and dead young were counted. After parturition, the rats were killed, the uteri and the attached mesometrium were exposed and the metrial glands were counted. The uteri were then excised, opened and checked for the presence of resorbing embryos. Ovaries were removed, the ovarian bursa was opened and CL were counted under a dissecting microscope.

Means, standard errors, statistical significance and percentages of difference were calculated for the following data: (1) oestrous cycle length and regularity; (2) number of CL; (3) number of Day-1 ova recovered and number fertilized; (4) number of Day-4 ova recovered and number developing; (5) number of metrial glands; (6) preimplantation losses (the difference between the number of CL and metrial glands expressed as percentage of $\mathrm{CL}$ ); (7) number of days to the 'placental sign'; (8) length of pregnancy; (9) total number of young born; (10) number of young born alive; (11) number of young born dead; (12) number of resorbing embryos in utero; (13) postimplantation losses (number of metrial glands less total number of young born as percentage of metrial glands); (14) perinatal losses (number of young born dead as percentage of metrial glands).

\section{RESULTS}

In our animals, chronic exposure to high environmental temperature had no 
effect on the number of cL, whether they were counted on Day 4 of pregnancy or after parturition. Pooling of the results (Table 1) suggests that the number of ova shed was also unaffected. Text-figure 1 summarizes the fate of these ova in the animals of both control and heat-acclimatized groups. In the latter group,

\section{TABLE 1}

LOSSES (MEAN/RAT) OF VARIOUS PARAMETERS IN CONTROL AND HEAT-ACGLIMATIZED RATS EXPRESSED AS A PERCENTAGE OF THE NUMBER OF CL

\begin{tabular}{|c|c|c|c|c|c|c|}
\hline & \multicolumn{2}{|c|}{ Control } & \multicolumn{2}{|c|}{ Heat-acclimatized } & \multirow{2}{*}{$\begin{array}{c}\% * \\
\text { difference }\end{array}$} & \multirow{2}{*}{$\begin{array}{l}\text { Level of } t \\
\text { significance }\end{array}$} \\
\hline & Means & S.E. & Means & S.E. & & \\
\hline No. of $\mathrm{CL}$ & $12 \cdot 3(35)$ & 0.312 & $11.9(28)$ & 0.242 & $-3 \cdot 3$ & NS \\
\hline $\begin{array}{l}\text { No. of Day-1 ova recovered } \\
\text { as } \% \text { of } \mathrm{CL}\end{array}$ & $\begin{array}{l}11 \cdot 1(16) \\
90 \cdot 2(16)\end{array}$ & $\begin{array}{l}0.273 \\
5 \cdot 427\end{array}$ & $\begin{array}{r}9 \cdot 3(10) \\
78 \cdot 2(10)\end{array}$ & $\begin{array}{l}0.471 \\
4.920\end{array}$ & $\begin{array}{l}-26 \cdot 2 \\
-13 \cdot 4\end{array}$ & $\begin{array}{l}0.01 \\
0.01\end{array}$ \\
\hline $\begin{array}{l}\text { No. of fertilized Day-1 } \\
\text { ova as } \% \text { of cL }\end{array}$ & $\begin{array}{l}10 \cdot 9(16) \\
88 \cdot 6(16)\end{array}$ & $\begin{array}{l}0.310 \\
4 \cdot 250\end{array}$ & $\begin{array}{r}8.8(10) \\
74.8(10)\end{array}$ & $\begin{array}{l}0 \cdot 468 \\
5 \cdot 392\end{array}$ & $\begin{array}{l}-19 \cdot 3 \\
-15 \cdot 6\end{array}$ & $\begin{array}{l}0.001 \\
0.01\end{array}$ \\
\hline $\begin{array}{l}\text { No. of Day-4 ova recovered } \\
\text { as } \% \text { of } \mathrm{CL}\end{array}$ & $\begin{array}{l}10 \cdot 9(15) \\
90 \cdot 2(15)\end{array}$ & $\begin{array}{l}0.342 \\
5 \cdot 427\end{array}$ & $\begin{array}{r}9 \cdot 0(11) \\
75 \cdot 6(11)\end{array}$ & $\begin{array}{l}0 \cdot 381 \\
4 \cdot 853\end{array}$ & $\begin{array}{l}-17 \cdot 4 \\
-16 \cdot 2\end{array}$ & $\begin{array}{l}0.001 \\
0.01\end{array}$ \\
\hline $\begin{array}{l}\text { No. of developing Day-4 } \\
\text { ova as } \% \text { of cL }\end{array}$ & $\begin{array}{l}10 \cdot 9(15) \\
88.6(15)\end{array}$ & $\begin{array}{l}0.284 \\
4 \cdot 341\end{array}$ & $\begin{array}{r}8 \cdot 1(11) \\
68 \cdot 1(11)\end{array}$ & $\begin{array}{l}0 \cdot 639 \\
5 \cdot 886\end{array}$ & $\begin{array}{l}-25 \cdot 7 \\
-23 \cdot 2\end{array}$ & $\begin{array}{l}0.001 \\
0.001\end{array}$ \\
\hline $\begin{array}{l}\text { No. of metrial glands } \\
\text { as } \% \text { of } \mathrm{cL}\end{array}$ & $\begin{array}{l}11 \cdot 0(20) \\
89 \cdot 4(20)\end{array}$ & $\begin{array}{l}0.319 \\
4.421\end{array}$ & $\begin{array}{r}8.2(14) \\
68.9(14)\end{array}$ & $\begin{array}{l}0.883 \\
5 \cdot 859\end{array}$ & $\begin{array}{l}-25 \cdot 5 \\
-22 \cdot 9\end{array}$ & $\begin{array}{l}0.01 \\
0.001\end{array}$ \\
\hline $\begin{array}{l}\text { No. of young born, total } \\
\text { as } \% \text { of cL }\end{array}$ & $\begin{array}{r}8.0(20) \\
65 \cdot 0(20)\end{array}$ & $\begin{array}{l}0.896 \\
3 \cdot 146\end{array}$ & $\begin{array}{r}5 \cdot 2(14) \\
43 \cdot 7(14)\end{array}$ & $\begin{array}{l}1 \cdot 115 \\
5 \cdot 624\end{array}$ & $\begin{array}{l}-35 \cdot 3 \\
-32 \cdot 8\end{array}$ & $\begin{array}{l}0.01 \\
0.001\end{array}$ \\
\hline $\begin{array}{l}\text { No. of young born alive } \\
\text { as } \% \text { of } \mathrm{CL}\end{array}$ & $\begin{array}{r}6 \cdot 9(20) \\
56 \cdot 1(20)\end{array}$ & $\begin{array}{l}1 \cdot 064 \\
4 \cdot 225\end{array}$ & $\begin{array}{r}3 \cdot 1(14) \\
26 \cdot 1(14)\end{array}$ & $\begin{array}{l}1.040 \\
5 \cdot 720\end{array}$ & $\begin{array}{l}-55 \cdot 1 \\
-53 \cdot 6\end{array}$ & $\begin{array}{l}0.05 \\
0.001\end{array}$ \\
\hline
\end{tabular}

TABLE 2

PROPORTIONATE* PREIMPLANTATION, POSTIMPLANTATION AND PERINATAL LOSSES IN CONTROL AND HEAT-ACCLIMATIZED RATS

\begin{tabular}{|c|c|c|c|c|c|c|}
\hline & \multicolumn{2}{|c|}{ Control } & \multicolumn{2}{|c|}{ Heat-acclimatized } & \multirow{2}{*}{$\stackrel{\% \dagger}{\text { difference }}$} & \multirow{2}{*}{$\begin{array}{c}\text { Level of } \ddagger \\
\text { significance }\end{array}$} \\
\hline & Means & S.E. & Means & S.E. & & \\
\hline $\begin{array}{l}\text { Preimplantation losses }(\%) \\
\text { Postimplantation losses }(\%) \\
\text { Perinatal losses }\end{array}$ & $\begin{array}{l}10 \cdot 6(20) \\
27 \cdot 3(20) \\
10 \cdot 0(20)\end{array}$ & $\begin{array}{l}0 \cdot 891 \\
1.845 \\
3 \cdot 100\end{array}$ & $\begin{array}{l}31 \cdot 1(14) \\
36 \cdot 6(14) \\
25 \cdot 6(14)\end{array}$ & $\begin{array}{l}1 \cdot 208 \\
2 \cdot 120 \\
3 \cdot 270\end{array}$ & $\begin{array}{r}+194 \cdot 1 \\
+34 \cdot 1 \\
+156 \cdot 0\end{array}$ & $\begin{array}{l}0.001 \\
0.001 \\
0.001\end{array}$ \\
\hline
\end{tabular}

* Defined in Materials and Methods.

$\dagger$ Control values $=100 \%$.

I Student's $t$ test (Steel \& Torrie, 1960).

() Number of animals.

preimplantation losses were due to absence of recoverable ova on the 1st day of pregnancy and to degeneration of some fertilized ova by Day 4. During the postimplantation period, there was some foetal resorption, and perinatal losses were due to death of foetuses around the time of parturition (Tables 1 and 2).

The effect of heat on the duration of oestrous cycle, the time of placentation, and the duration of pregnancy is shown in Table 3 and Text-figs. 2 and 3. 
During the same period ( 40 days), the animals of the heat-acclimatized group had fewer oestrous cycles than the controls and their mean cycle length was of

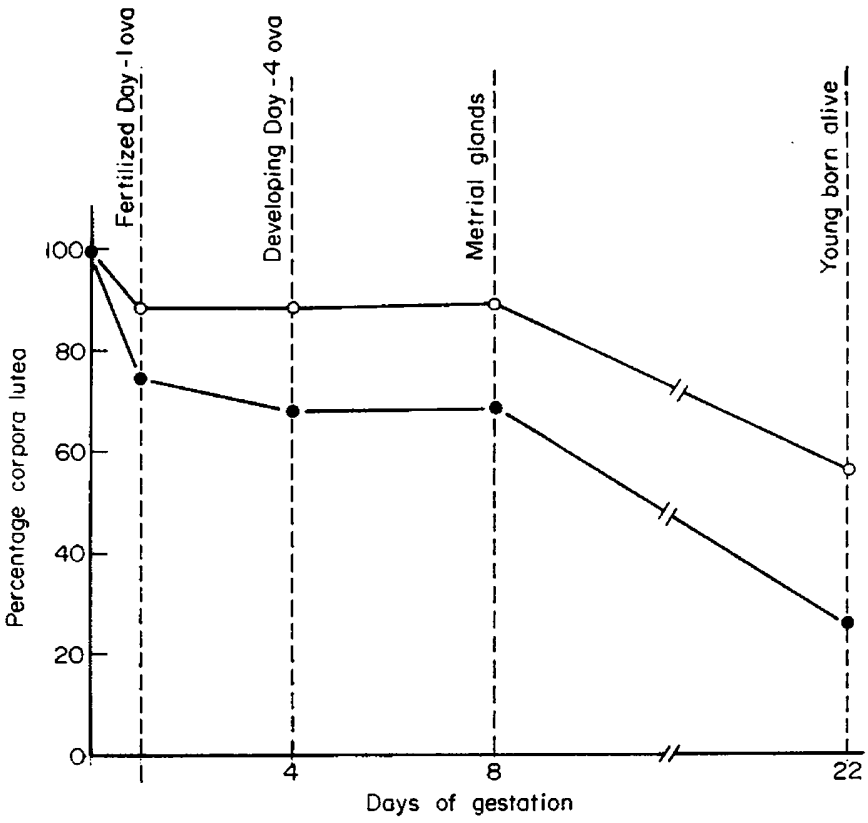

TExT-FIG. 1. Losses throughout gestation expressed as a percentage of the number of ova shed (estimated by the number of $\mathrm{CL}$ ).

TABLE 3

TIME PARAMETERS IN THE REPRODUCTIVE GYCLES OF CONTROL AND HEAT-ACGLIMATIZED RATS

\begin{tabular}{|c|c|c|c|c|c|c|}
\hline & \multicolumn{2}{|c|}{ Control } & \multicolumn{2}{|c|}{ Heat-acclimatized } & \multirow{2}{*}{$\begin{array}{c}\%^{*} \\
\text { difference }\end{array}$} & \multirow{2}{*}{$\begin{array}{l}\text { Level of } \\
\text { significance }\end{array}$} \\
\hline & Means & S.E. & Means & S.E. & & \\
\hline $\begin{array}{l}\text { No. of oestrous cyles/ } \\
\text { animal/40 days } \\
\text { Mean cycle length (days) } \\
\text { No. of cycles longer than } 4 \\
\text { days } \% \% \text { ) } \\
\text { No. of days to 'placental } \\
\text { sign' } \\
\text { Duration of pregnancy } \\
\text { (days) } \$\end{array}$ & $\begin{array}{c}9 \cdot 2(20) \\
4 \cdot 3(20) \\
34 \cdot 8(20) \\
13 \cdot 4(9) \\
22 \cdot 1(20)\end{array}$ & $\begin{array}{l}0.195 \\
0.065 \\
5.473 \\
0.556 \\
0.109\end{array}$ & $\begin{array}{r}8.7(17) \\
4.7(17) \\
49.3(17) \\
14.0(10) \\
21.6(14)\end{array}$ & $\begin{array}{l}0.413 \\
0.151 \\
8.850 \\
\\
0.314 \\
0.702\end{array}$ & $\begin{array}{r}-5 \cdot 4 \\
+9 \cdot 3 \\
+41 \cdot 7 \\
+4.5 \\
-2 \cdot 2\end{array}$ & $\begin{array}{l}0.05 \dagger \\
0.01 \ddagger \\
0.01 \dagger \\
\text { NS } \\
\text { NS }\end{array}$ \\
\hline
\end{tabular}

* Control values $=100 \%$.

$\uparrow$ Student's $t$ test (Steel \& Torrie, 1960).

$\mp$ Calculated according to both Student's $t$ test (Steel \& Torrie, 1960) and Mann-Whitney U test for non-parametric values (Segal, 1956).

Only for rats which were delivered spontaneously.

( ) Number of animals.

somewhat longer duration (Table 3). The heat treatment also affected the regularity of the oestrous cycle. This was expressed by a significant increase in 
the frequency of cycles both longer and shorter than the 'mean' length anticipated. The animals in the heat-acclimatized group had $41.7 \%$ more cycles longer than 4 days as compared with those of the control group (Table 3 and Text-fig. 2.)

Heat apparently did not affect the time of implantation as suggested by the similar interval between mating and the appearance of the 'placental sign' (Table 3).

With respect to the duration of pregnancy, the heat-acclimatized group could be divided into two subgroups: (i) animals which were delivered after a

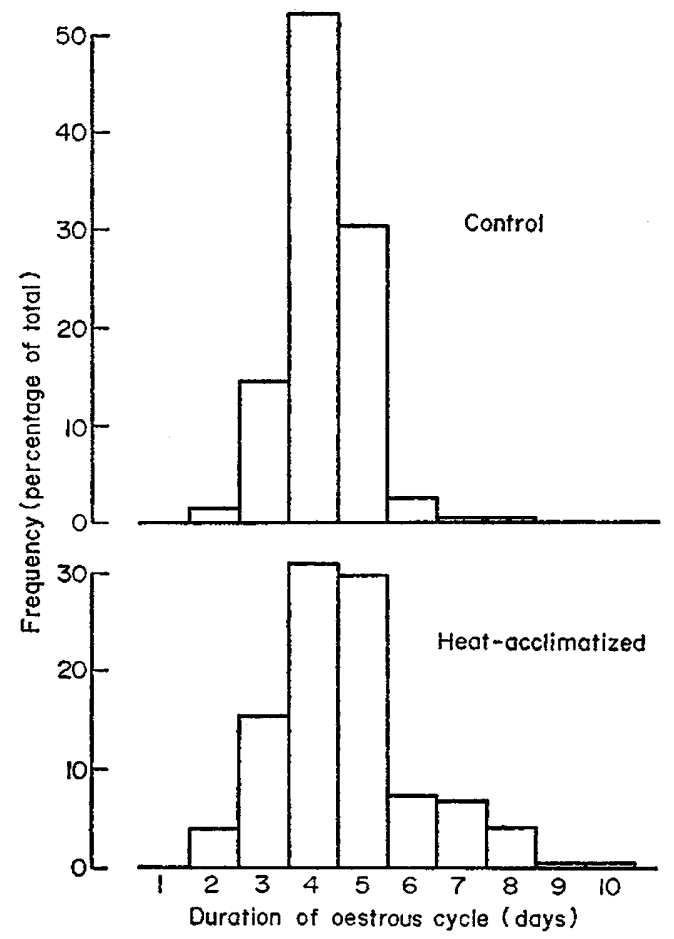

Text-FIG. 2. Frequency distribution of oestrous cycles of various durations. Results are significantly different at the $1 \%$ level $\left(\chi^{2}\right)$ (Segal, 1956).

mean gestation period of about 22 days ( $71 \%$ of total); and (ii) animals which were not delivered until the $33 \mathrm{rd}$ day or later $(29 \%)$. The latter were delivered surgically. All the control animals were delivered of their foetuses at approximately 22 days (Text-fig. 3 ).

All females in the control group were delivered between the 21st and 23rd day of gestation, with a mean duration of pregnancy of $22 \cdot 1$ days. However, only $36 \%$ of the animals in subgroup (i) of the heat-treated animals were delivered at this time. Deliveries in this group were spread between the 18th and the 25th day of gestation (Text-fig. 3, Table 2). In addition, in the heat-acclimatized subgroup (i), parturition was extended with long intervals between the delivery of individual foetuses. Parturition would start at any time and last for 
8 to $12 \mathrm{hr}$ or more in a few cases. Animals in the control group were delivered of their litters in a relatively short time, one foetus following the other. Parturition was usually over before noon.

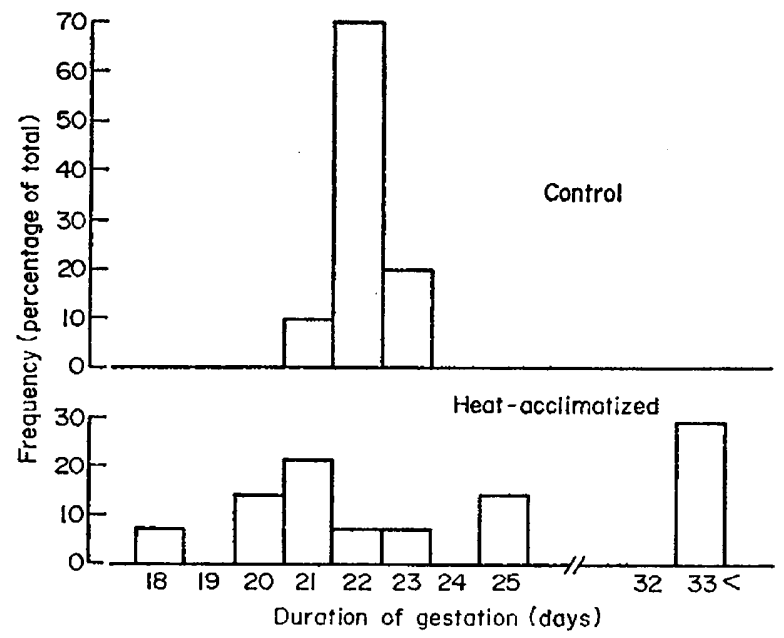

Text-Fig. 3. Frequency distribution of pregnancies of various durations ending in spontaneous delivery.

\section{DISCUSSION}

In general, the timing and magnitude of prenatal losses in females exposed to $35^{\circ} \mathrm{C}$ were similar to those obtained by earlier investigators (Macfarlane $e t$ al., 1957; Pennycuik, 1964c). However, contrary to the results obtained by Macfarlane et al. (1957) and Pennycuik (1964c), we found no reduction in the number of cL in the heat-treated group (Table 1). In their experiments, these investigators made CL counts on Day 16 of gestation. Macfarlane et al. (1957) suggested that the reduced counts might be due to some failure of luteinization at the higher temperature. Our results negate this possibility because similar CL counts were found in both animals killed on Day 4 of gestation and those killed after parturition. The different results obtained by Macfarlane et al. (1957) may also be due to their animals having been offered a low protein diet. Protein deficiency is known to reduce cL numbers (Gupta \& Lacy, 1967). This explanation is also doubtful since Pennycuik (1964a) observed similar reductions in CL counts in animals on low and high protein diets.

Preimplantation losses in the animals exposed to $35^{\circ} \mathrm{G}$ were three times greater than those in the controls. This rate was higher than that observed by Pennycuik (1964c) who noted only a two-fold increase at higher environmental temperature. Our results show that these increased preimplantation losses at $35^{\circ} \mathrm{C}$ were due to the higher incidence of cL unaccounted for by Day-1 ova $\left(21.8 \%\right.$ at $35^{\circ} \mathrm{C}$ as opposed to $9.8 \%$ at $22^{\circ} \mathrm{C}$, calculated from Table 1$)$ and to an increase in the number of ova which were degenerating by Day 4 of gestation $\left(10 \%\right.$ at $35^{\circ} \mathrm{C}$ as opposed to none at $22^{\circ} \mathrm{C}$, calculated from Table 1$)$. 
The fate of the missing Day-1 ova in the heat-treated group is uncertain. They may have been expelled, may have degenerated rapidly, or may have been trapped in luteinizing follicles which did not rupture. The latter process has been observed and described by Evans (1925). Whether these losses were due to the effects of heat on the maternal tissue (Shah, 1956) or on the developing ova, as was shown to be the case in acute exposure to heat (Chang, 1957; Fernandez-Cano, 1958; see review, Waites, 1968), is uncertain.

Fertilization and implantation did not contribute to the preimplantation losses. The percentage of fertilized ova from those recovered on Day I was 98.3 and 94.9 for the heat-treated group and for the control group, respectively. Judging by the number of metrial glands on the day of parturition, all developing ova which were present on Day 4 were implanted (Table 1). There was, therefore, no evidence that heat affected the implantation process, contrary to the suggestion put forward by Macfarlane et al. (1957, 1959). The slight discrepancies between the numbers of fertilized Day-1 ova and Day-4 ova recovered, and between the numbers of developing Day-4 ova and metrial glands (Table 1), are due to the use of different groups of animals for the different observations.

In both groups of rats, postimplantation losses were larger than perinatal losses (Table 2). However, heat treatment increased the postimplantation losses by $34 \%$ and the perinatal losses by $156 \%$ as compared with the controls (Table 2).

The duration of the oestrous cycle in the heat-acclimatized animals differed from that in the controls whether it was assessed in terms of mean cycle length or the number of cycles occurring during a given period of time. The results are at variance with those obtained by Pennycuik (1964c) who observed that, at a variety of constant temperatures, the duration of the oestrous cycle was increased compared with that observed at diurnally fluctuating room temperatures. Our results are, however, in accordance with earlier observations in this laboratory using animals kept at constant temperatures (Sod-Moriah \& Pollack, 1970).

Macfarlane et al. (1959) reported that pregnancy was prolonged in animals exposed chronically to higher environmental temperatures, but in all cases their animals were finally delivered spontaneously. In our experiment, the rats of the heat-treated group were either delivered of their litters after approximately the same gestation period as the controls, or foetuses were retained in utero until the time of autopsy 33 days after coitus. This latter group was not observed by previous investigators (Macfarlane et al., 1957; Macfarlane $e t$ al., 1959; Pennycuik, 1964c). Underfeeding is known to delay implantation (Shapira, 1969) and the prolonged gestation observed may have been due to protein deficiency as a result of reduced food intake. It has been observed (Pennycuik, 1964a) that gestation was shorter in heat-acclimatized animals offered a protein-rich diet than in those offered a diet containing only $15 \%$ of protein. This may be the explanation for those animals which were delivered spontaneously in our experiment, were offered a diet containing $28 \%$ protein (Sod-Moriah \& Pollack, 1970), and in which the interval between mating and the appearance of the 'placental sign' was similar in animals at $35^{\circ} \mathrm{C}$ and at 
the control temperature. It does not, however, account for the $29 \%$ of the animals at $35^{\circ} \mathrm{G}$ which failed to deliver.

It is suggested that heat treatment affected the processes involved in labour and delivery. This suggestion is substantiated by the larger variation around the mean in the duration of gestation in those animals which were delivered spontaneously, and by the prolongation of parturition in this group. The animals which retained their foetuses in utero well beyond term may represent the proportion of the population in which the parturition process failed entirely. Disturbances in these processes may be associated with increased perinatal losses.

Some of the discrepancies between our results and those reported by others may be due to difference in the strain of rats used, difference in the temperatures applied or difference in the age of the animals at the time of exposure to the elevated temperatures.

\section{ACKNOWLEDGMENTS}

Special thanks are due to Dr R. P. Pennycuik for valuable discussion and constructive advice. The author also wishes to thank Dr P. F. Kraicer for helpful comments. Appreciation is also expressed for the technical assistance of Mrs C. Madar and to Mrs Cynthia Bellon for skilful editing of the manuscript.

\section{REFERENGES}

Chang, M. G. (1957) Effect of pyrogen on embryonic degeneration in the rabbit. Fedn Proc. Fedn Am. Socs exp. Biol. 16, 21.

Evans, H. M. (1925) The function of the anterior hypophysis. In: The Harvey Society Lectures, Series 19, p. 212. Lippincott, Philadelphia.

Fernandez-Gano, L. (1958) Effect of increase or decrease of body temperature and hypoxia on pregnancy in the rat. Fert. Steril. 9, 455.

GuPTA, S. R. \& LACY, B. (1967) Effects of protein calorie deficiency on the reproductive performance of female rats. Ind. F. med. Res. 55, 904.

Hafez, E. S. E. (1968) Environmental effects on animal productivity. In: Adaptation of Domestic Animals, p. 74. Ed. E. S. E. Hafez. Lea \& Febiger, Philadelphia.

KraICER, P. F. (1967) Studies on the mechanism of nidation. XXIV. Isolation and study of intrauterine ova from the rat: technique and observations. Int. F. Fert. 12, 320.

Macfarlane, W. V., Pennycutk, R. R. \& Thrift, E. (1957) Resorption and loss of foetuses in rats living at $35^{\circ}$ G. F. Physiol., Lond. 135, 451.

Macparlane, W. V., Pennycuix, R. P., Yeates, N. T. M. \& Thrift, E. (1959) Reproduction in hot environments. In: Recent Progress in the Endocrinology of Reproduction, p. 81. Ed. G. W. Lloyd. Academic Press, New York.

Pennycutk, R. P. (1964a) The effects on rats of chronic exposure to $34^{\circ} \mathrm{C}$. I. The effect of variations in the diet on growth and on the ability of mothers to rear pups to weaning age. Aust. $\mathcal{F}$. biol. Sci. 17, 208.

Pennycuix, R. P. (1964b) The effects on rats of chronic exposure to $34^{\circ} \mathrm{C}$. III. Appetite and the efficiency of food conversion. Aust. 7. biol. Sci. 17, 236.

Pennycuik, R. P. (1964c) The effect on rats of chronic exposure to $34^{\circ} \mathrm{C}$. IV. Reproduction. Aust. $\mathcal{J}$. biol. Sci. 17, 245.

SEGAL, S. (1956) Non-parametric statistics for the behavioral sciences. McGraw-Hill, New York.

SHAH, M. K. (1956) Reciprocal egg transplantations to study the embryo-uterine relationship in heatinduced failure of pregnancy in rabbits. Nature, Lond. 177, 1134.

Shapira, N. (1969) Pregnancy performance of lactating rats maintained at three nutritional levels. M.Sc. thesis, Faculty of Agriculture, The Hebrew University, Jerusalem.

Sod-Moriah, U. A. \& Pollack, E. (1970) Food and water consumption and the reproductive performance of the heat-acclimated female rat. Int. F. Biochim. Biomet. 14, 293. 
Steel, R. G. D. \& Torrie, J. H. (1960) Principles and procedures of statistics. McGraw-Hill, New York.

Sundstroem, E. S. (1927) Physiological aspects of tropical climates. Physiol. Rev. 7, 320.

Sundstroem, E. S. (1930) Contribution to tropical biochemistry and physiology. II. Supplementary experiments on rats adapted to graded levels of reduced cooling power. Univ. Calif. Publs Physiol. 7, 103.

Venable, J. W. (1939) Intra-uterine bleeding in the pregnant albino rat. The 'placental sign'. Anat. Rec. 74, 273.

Wartes, G. M. H. (1968) Temperature and fertility in mammals. VIth Int. Congr. Anim. Reprod. Artif. Insem., Paris, 1, 235.

YeATEs, N. T. M. (1956) The effect of high air temperature on pregnancy and birth in Merino sheep. Aust. F. agric. Res. 7, 435. 